\title{
人工酸性雨による造園用植物への影響と指標性
}

$$
\begin{array}{llll}
\text { 三 } & \text { 沢 } & \text { 彰* } \\
\text { 永 } & \text { 井 智 雄* }
\end{array}
$$

Damage to Plants for Landscaping by Acid Rain

Akira Misawa

Tomoo Nagal

\begin{abstract}
摘要：酸性雨による植物被害について、主に造園用植物を供試体にして実験を行つた。人二酸性液を用い、酸性度 の違い、器官別差異、葉の生有ステージによる障害の差異などについて検討した。その結果、わが国の場合、酸性 雨によって樹木葉が可視障害を受ける可能性はないと考えられた。しかし、花弁では種類によっては障害が発現す る可能性があり、指標性を考える上では今後、より感受性の高い種類を見い出すことが必要である。
\end{abstract}

\section{1. 研究の背墨及び目的}

近年, 広域大気污染として降雨の酸性化, すなわち酸 性雨の問題がクローズアップされてきた。世界で最も酸 性度の低い値としては, 1964 年に PH 2.1 の降雨がアメ リカ北東部で記録されており, わが国でも1973年に静岡, 山梨両県で PH 2.7 〜.5 が記録されている。

この酸性雨の問題はヨーロッパでは, 国境を越える大 気污染としても重視され, 湖沼の酸性化, 土㙵の悪化, 植物への影響等, 自然生態系に及ぼす影響が問題視され ている。わが国では降雨時に眼や皮虑に対する刺激を訴 える人体影響, アサガオ・ッツジ等の花弁の漂白化, 農 作物の被害といった事例によって問題となった。このた め植物被害に関しては農作物についていくつかの実験報

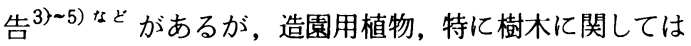
皆無に近い。そこで, 本研究では造園用植物への直接影 響を調べるために人工酸性液を用い, 植物葉と花弁に散 布を行い葉・花弁によ゙のような可視障害が発現するかを 観察した。また, 人工酸性雨の濃度 (酸性度) による差 異, 供試植物の種による差異等について検討し, さらに 同一種においても葉の状態により被害の発現に差異が認 められたことから, その新葉と旧葉とで葉身自体の $\mathrm{PH}$ - 含水量の測定を行ない可視障害の発生との関連を追求 した。また, 酸性雨に対する植物の指標性についても検 討した。

なお, 酸性雨とは酸性降下物のひとつである。酸性降 下物の中には, 雨を始めとして雪も霧も含まれる。乙の ように酸性降下物は液体の状態で降下してくるものと, 乾いた状態で降下してくるものとがある。液体で降下す
るあのを wet deposition, 乾いた状態で降下するあの を dry deposition という。降下量としては前者が70 \%, 後者が30\%といわれているが, 植物への影響からみ れば，その割合は逆転するという報告もある。，7)

一般に降水は空気中の二酸化炭素により弱酸性 ( $\mathrm{PH}$ 5. $6 〜 5.7$ ）を示す。それが硫黄酸化物や窒素酸化物之 いった大気污染物質によってさらに強い酸性を示すよう になったあのが酸性雨である。化石燃料の燃焼等により 大気中に放出された硫黄酸化物や窒素酸化物は rainout や washout の過程を経て雨中に取り込まれて地上に落 下する。乙のようにして雨中に取り込まれた二酸化硫黄 や空素酸化物は, 種々の化学反応を経て亜硫酸, 硫酸, 硝酸等に変化し, 降雨の酸性化をまねく。乙の機構から あ理解されるとおり, 降り始めの降水に比べて降水量が 増すに従って大気中の污染物質が洗浄, 除去されるため, 時間の経過ととあに降水の $\mathrm{PH}$ 值は高くなる。降水の酸 性化の原因物質として, $\mathrm{SO}_{4}^{2-}, \mathrm{NO}_{3}^{-}, \mathrm{C} \mathrm{I}^{-}$が一般に 考えられているが，いずれが主原因になっているかにつ いては現在のとてろ結論がでていない。列ただ,アメリカ 北東部に降った 1973 年の PH 4.05 の雨水では, 酸性度 の貢献度は $\mathrm{SO}_{4}^{2-}$ が $65 \%, \mathrm{NO}_{3}^{-}$が30\%, $\mathrm{CI}^{-}$が $5 \%$ と 計算されており,さらに近年は $\mathrm{NO}_{3}^{-}, \mathrm{C} \mathrm{I}^{-}$の貢献度の 上昇が確認され9 わが国でも同様の傾向が認められてい る。1

\section{2. 研究の方法}

$2-1$ 人工酸性液の作成

$98 \%$ 硫酸と純水で PH $1.0 （ 0.1 \mathrm{~N}$ ）の硫酸水溶液を 作り,さらにこの水溶液を純水で希釈することにより所

* 千葉大学園芸学部環境緑地学科 
定の $\mathrm{PH}$ 值の人工酸性液を作成した。また，61\%硝酸， $36 \%$ 塩酸と純水でそれぞれPH 2（0.01 N) の水溶液を 作り，硫酸之同様に硝酸・塩酸の各所定の $\mathrm{PH}$ 值の人工 酸性液を作成した。

\section{$2-2$ 散布方法}

ハンドスプレーとマイクロピペットによる 2 種類の方 法で散布を行なった。ハンドスプレーによる散布は，葉 の散布面に対して垂直になるようにして約 $10 \mathrm{~cm}$ 離れたと ころから行った。散布量はハンドスプレーの引き金をい っぱいまで握り散布するのを 1 回とし, 花弁には 1 回, 広葉には 2 回, 針葉には 5 回それぞれ散布した。この回 数 (散布量) は, 散布面に水滴が一様に付着する量であ る。なお，てのハンドスプレーの 1 回の噴出量は $0.7 \mathrm{ml}$ であった。一方のマイクロピペットによる散布は, 供試

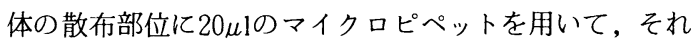
ぞれの量をスポット状に落して散布した。

散布を行なった時間は, 水分の蒸発が多いと考えられ る正午から午後 2 時の間とし，1日 1 回行った。なお， 葉への散布は可視障害の発現まで連日行った。

\section{$2-3$ 観察方法}

肉眼及びルーペを用いて可視障害の有無を観察した。 $2-4$ 供試体の $\mathrm{PH}$ 值測定

供試体 $1.0 \mathrm{~g}$ に $3.0 \mathrm{ml}$ の純水を加えて, すり鉢と乳棒 ですりつぶし，それをろ紙よってろ過した液を $\mathrm{PH} メ$ 一タで測定した。使用した PHメータは日立・堀場 $\mathrm{PH}$ メータ・H一7デジタルシリーズで $\mathrm{PH}$ 複合電極の内部 電極には $\mathrm{AgCl}$, 比較電極には $\mathrm{AgCl} ・ \mathrm{KCl}$ を使用 した。

\section{$2-5$ 供試体の含水量の測定}

供試体 $5.0 \mathrm{~g}$ を赤外線水分計で $120^{\circ} \mathrm{C}$ 下に保ちその減 少含水量を 1 分每に追跡し, 脱水の経時的変化について 測定した。

\section{$2-6$ 実験経過及び供試材料}

8 月上旬から 9 月中旬に行ったあのを測定 I, 10月上 旬から中旬に行ったものを測定 II，11月下旬から12月上 旬に行ったものを測定 III として各時期において千葉大学 園芸学部内におりる植物の葉及び花弁に $2-2$ の方法に より人工酸性液の散布を行った。各測定ごとの供試植物 は次のとおりである。

測定 I

$\begin{array}{ll}\text { ムクゲ } & \text { Hibiscus syriacus } \\ \text { ノウゼンカズラ } & \text { Campsis grandiflora } \\ \text { ビョウヤナギ } & \text { Norysca chinensis var. sali- } \\ & \text { cifolia } \\ \text { キョウチクトウ } & \text { Nerium indicum } \\ \text { アベリア } & \text { Abelia grandiflora } \\ \text { スギ } & \text { Clyptomeria japonica } \\ \text { ミズキ } & \text { Cornus controversa }\end{array}$

$\begin{array}{ll}\text { アカソ } & \text { Boehmeria tricuspis } \\ \begin{array}{l}\text { イヤカエデ } \\ \text { 測定II }\end{array} & \text { Acer mono } \\ \text { シナサワグルミ } & \text { Pterocarpa stenocarpa } \\ \text { カジカエデ } & \text { Acer diabolicum } \\ \text { ヌルデ } & \text { Rhus chinensis } \\ \text { フジ } & \text { Wisteria floribunda } \\ \text { サワラ } & \text { Chamaecyparis pisifera } \\ \text { サンゴジュ } & \text { Viburnum awabuki } \\ \text { ベニカナメ } & \text { Photinia glabra } \\ \text { ネズミモチ } & \text { Ligustrum japonicum } \\ \text { スギ } & \text { 前掲 }\end{array}$

測定 III

$\begin{array}{ll}\text { サザンカ } & \text { Camellia sasanqua } \\ \text { キク } & \text { Chrysanthemum morifolium } \\ \text { サンゴジュ } & \text { 前掲 } \\ \text { モッコク } & \text { Ternstroemia japonica } \\ \text { カイズカイブキ } & \text { Juniperus chinensis var } \\ & \text { kaizuka } \\ \text { セイョウヒイラギ } & \text { Ilex aquifolium } \\ \text { サカキ } & \text { Cleyera japonica } \\ \text { マテバシイ } & \text { Pasania edulis } \\ \text { キョウチクトウ } & \text { 前掲 } \\ \text { ベニカナメ } & \text { " } \\ \text { ネズミモチ } & \text { " }\end{array}$

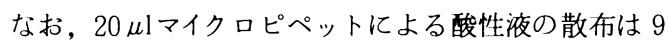
月 4 日実施した。また10月 4 日にムクゲ紫花に硫酸, 硝 酸, 塩酸を人工酸性液として $20 \mu \mathrm{l}$ マイクロピペットによ って散布を行った。測定四においてキク, サザンカの花 弁について $\mathrm{PH}$ 值測定を行い，ベニカナメ，ネズミモチ， サカキ, セイヨウバクチノキ, マテバシイについて新葉 -旧葉を区別して実験を行い, 供試葉の PH 值, 含水量 の測定を行った。

\section{$2-7$ 実験条件}

ハンドスプレーによる散布実験は，スギについては自 然降雨の影響がないようにビニール屋根のもとで行った が，他は全て学部内に生育している状態のままで行った。 また, マイクロピペットによる散布は, 花を切りとりフ ラスコに水差しして研究室内で行い，8時間後に可視障 害の発生を観察した。

\section{3. 結果及ひ考察}

葉及び花弁に対する硫酸人工酸性液の散布結果は表一 $1 \sim 5$ のとおりであった。なお, 表一 3 は酸性液の成分 の違いによる比較実験の結果である。また, 図一 1 亿花 弁の $\mathrm{PH}$ 值を, 図一 2 亿新葉と旧葉での $\mathrm{PH}$ 値と含水量 の測定結果を示した。以下に結果の概要を述べ, 項目別 に考察を加えるとととする。 


\section{表一1＼cjkstart花に対する酸性液散布の影響}

\begin{tabular}{|c|c|c|c|c|c|}
\hline & & & p H & & \multirow{2}{*}{ 诺 } \\
\hline & & 2.0 & 2.5 & 3.0 & \\
\hline \multirow{2}{*}{ ノウゼンカズラ } & 花弁 & + & + & + & \\
\hline & 菒 & $3-$ & - & - & \\
\hline \multirow{2}{*}{ ビヨウヤナギ } & 花并 & + & + & - & 水商状に杀のよちどり \\
\hline & 莱 & $3-$ & - & - & \\
\hline \multirow{4}{*}{ キョウチクトウ } & 白 & + & + & - & \\
\hline & 花弁桃 & + & + & - & 水滴状に赤のふちどり \\
\hline & 赤 & + & + & - & \\
\hline & 兆の菙 & $3-$ & - & - & \\
\hline \multirow{4}{*}{ ムクゲ } & 白 & + & + & + & 白色から透明に变化 \\
\hline & 柴 & + & + & + & \\
\hline & 八重の紫 & + & + & - & \\
\hline & 白の葉 & $3-$ & - & - & \\
\hline \multirow[t]{2}{*}{ アベリヤ } & 花弁 & + & - & - & 水滴状に茶のふちどり \\
\hline & 白 & + & + & - & 水滴状に茶のふちどり \\
\hline \multirow[t]{2}{*}{ サザンカ } & 花弁桃 & + & + & - & \\
\hline & 八重の赤 & + & + & \pm & \\
\hline \multirow{3}{*}{$\neq$} & 白 & + & - & - & 白色から透明に変化 \\
\hline & 花弁黄 & + & + & - & 黄色から透明に変化 \\
\hline & 紫 & + & - & - & \\
\hline
\end{tabular}

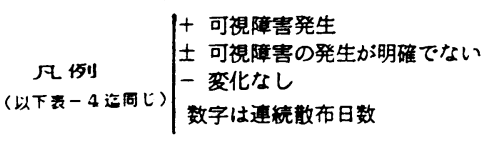

表一2 マイクロピペットによる酸性夜散布の影留

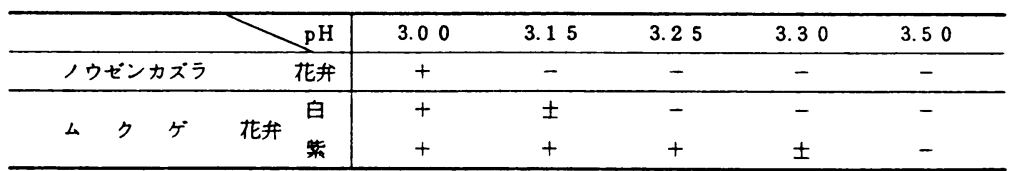

\section{$3-1$ 人工酸性液の $\mathrm{PH}$ 值と可視障害}

硫酸人工酸性液による植物葉への可視障害の発生之酸 性液の $\mathrm{PH}$ 值との関係については, いくつかの研究報告 がある。それらの結果は, 人工酸性液の散布量, 散布方 法, 散布回数等に若干の差異はあるものの, 葉に関して は PH 3.0 より低い値になると可視障害の発生が認めら れる点でほぼ一致している。本測定においても酸性雨に 弱いとされているスギが PH 2.5 で連日散布17日後に障 害が発生し, ベニカナメ, フジ, サワラも PH 2.5 で障 害が発現したが, PH 3.0 以上で発現したものはなかっ た。

一方，花弁に対する実験では，ほとんどの供試体が PH 2.5 で散布後, 翌日可視障害が発生しており, それぞれ の葉と比較して屯明らかに花弁の方が障害が発生しやす い。その中でもノウゼンカズラ, ムクゲの白花, 紫花は それぞれ PH 3.15，3.30 の硫酸人工酸性液 $20 \mathrm{ml}$ の散布 により障害が発生しており，その感受性の高さが認めら れた。

わが国の場合，PH 3.0 以下の酸性雨が連続して降る ということは考えられず，したがって葉に対する可視障
害が天然の降雨によって発現する恐れはないよいえよう。 しかし，花弁に対しては感受性の高い植物なら可視障害 の発現が十分考えられ，乙れらの植物による酸性雨の指 標性が認められた。

\section{$3-2$ 水滴の形状と可視障害}

酸性液による可視障害は散布した水滴の存在した筒所 に発生する。その水滴が大きく厚いほど可視障害の発生 は著しい。乙れは酸性液が植物の組織面を破壊するのは, その面の一定面積あたりの酸性液の浸透量によって決定 されること,さらに酸性液は浸透後, あまり移動してい ないてとを示唆している。直径の大きな水滴では, 水滴 の周辺から小さくなり, 障害は水滴の中心に生ずること 屯観察された。乙れは水滴の中心ほよ゙酸性液の浸透量が 多くなっているため, と考えられた。また, 水滴中の水 分が蒸発し硫酸等が濃縮することによる酸性度の低下の 影響屯考えられる。

一方, 花弁への散布実験では水滴がふちどりされたよ うに脱色が観察されるものがあった。ムクゲの白色, キ クの白花, 黄花では透明に脱色したのに対して, サザン カの白花, ビヨウヤナギの黄花では, それぞれ茶色のふ 
表一３ ムクゲ紫花の人工酸性雨による影響

\begin{tabular}{|c|c|c|c|c|c|}
\hline & $\mathrm{pH}$ & 2.50 & 2.75 & 3.00 & 3.25 \\
\hline 硫 & 酸 & + & + & + & + \\
\hline 硝 & 酸 & + & + & - & - \\
\hline 塩 & 酸 & + & + & - & - \\
\hline
\end{tabular}

\section{表一4 葉に対する酸性液散布の影響}

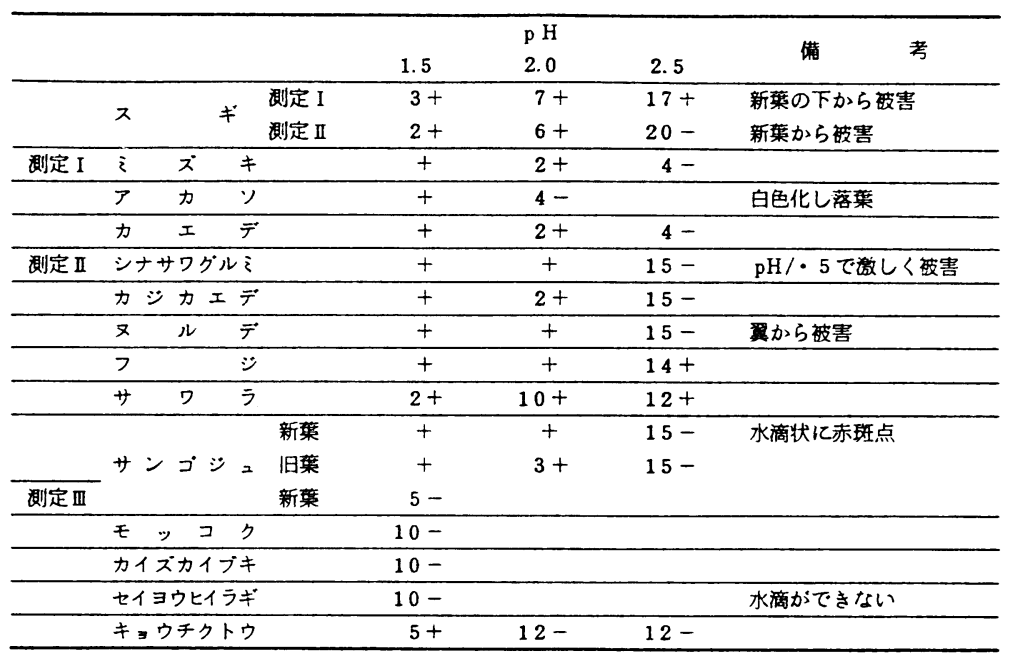

表一 5 葉に対する酸性液散布の影響（新葉と旧葉との比較）

\begin{tabular}{|c|c|c|c|c|c|c|}
\hline & & & \multicolumn{4}{|c|}{$\mathrm{pH}$} \\
\hline & & & 1.5 & 2.0 & 2.5 & 3.0 \\
\hline \multirow{4}{*}{ ベニカナメ } & \multirow{2}{*}{ 剧定 II } & 新保 & + & + & \multirow[t]{4}{*}{$4+$} & \multirow[t]{4}{*}{$11-$} \\
\hline & & 旧葉 & $3+$ & $15-$ & & \\
\hline & \multirow{2}{*}{ 利定 II } & 新葉 & + & $10-$ & & \\
\hline & & 旧葉 & $5-$ & & & \\
\hline \multirow{4}{*}{ ネズミモチ } & \multirow{2}{*}{ 测定 II } & 新葉 & + & + & \multirow[t]{2}{*}{$15-$} & \\
\hline & & 旧葉 & + & $15-$ & & \\
\hline & \multirow{2}{*}{ 测定 III } & 新葉 & $2+$ & $10+$ & \multirow[t]{2}{*}{$10-$} & \\
\hline & & 旧葉 & $2+$ & $10-$ & & \\
\hline \multirow{2}{*}{ サ 力 } & \multirow{2}{*}{ 测定 II } & 新葉 & $2+$ & $5+$ & \multirow{2}{*}{\multicolumn{2}{|c|}{$\begin{array}{l}10- \\
10-\end{array}$}} \\
\hline & & 旧葉 & $5+$ & $10+$ & & \\
\hline \multirow{2}{*}{$\begin{array}{l}\text { セイヨウ } \\
\text { バクチノキ }\end{array}$} & \multirow{2}{*}{ 测定 III } & 新葉 & $5+$ & $10-$ & & \\
\hline & & 旧葉 & $8+$ & $10-$ & & \\
\hline \multirow{2}{*}{ マテバシイ } & \multirow{2}{*}{ 即定 III } & 新葉 & $3+$ & $10-$ & & \\
\hline & & 旧葉 & $10-$ & & & \\
\hline
\end{tabular}

ちどりが生じ，その内側が脱色した。

また, サザンカ, ツバキの葉は酸性液を散布すると水 滴が形成されず，葉面が一様に濡れたような状態になり， 可視障害が生じにくく, 重力落下の方向の下側の葉縁か ら障害が発現した。つまり, 水滴とならないためにその 厚さが薄くなり一定面積あたりの酸性液の浸透量が少な くなることにより可視障害が発生しにくく, 重力落下の 方向に液がたまるため, その部分から障害が発生するす のと考察された。
3-3 供試体の生理状態亡可視障害

葉の可視障害は, 秋（測定 II）より冬 (測定 III), 新葉 より旧葉の方が発生しにくいという結果であった。秋よ り冬という季節的変化は, 日照・温度・湿度などの気象 の変化む考えられるが, ここでは秋から冬の時間的変化, つまり葉が新葉から旧葉化すると考え, 新葉と旧葉の生 理的差異と可視障害との関係について考察してみたい。 硫黄酸化物による植物影響は生長し終った新葉に生じ やすいという報告 ${ }^{10)}$ がある。本実験であスギにおいて同 
様の結果が得られた。スギは 8 月下旬の実験では新葉よ りも下方の幹よりの成葉から障㝬が発生したのに，9月 中旬の実験では新葉から発生した。てれは 8 月下旬には まだ生長し終っていなかった新葉が 9 月中旬には成葉化 したためではないか, と推定された。測定吕（冬）の実 験でも, 明らかに新葉より旧葉の方が障嗐が発生しにく いととがわかる（表一5）。乙の原因を検討するために新 葉, 旧葉それぞれの PH 值, 含水量を測定した結果が図 - 2である。供試体の PH 值が高ければ散布される人工 酸性液との $\mathrm{PH}$ 值差がひろがり, 酸性度によるストレス が大きくなって可視障害が発生しやすいのではないかと 考えられたからである。しかし, 結果はネズミモチ以外 はすべて旧葉の方が PH 値は高かった。特に可視障害の 差異の著しいベニカナメにおいては, PH 值にして 0.7 旧葉の方が高い値であった。乙れらは上記の仮説とは逆 の結果であり, PH 値が 7.0 亿近いということは, 安定 した状態にあるといえるのであって, 供試体の酸性度が 小さいということは, それだけ水素イオンに対する緩衝 能力が大きく, 人工酸性液の浸透に対してあ抵抗性を示 すむのと考えられた。

次に供試体の含水量であるが, 乙れは水素イオンに対 する緩衝機能が含水量によって影響されるのではないか という仮定による。しかし，結果はこれあ逆であった。 水素イオンの緩衝機能は解離した有機酸や塩基性物質が 関与しているという研究報告もある。含水量による緩衝 機能の差は存在しないといえよう。なお, 新葉は旧葉に 比べて組織が柔らかである。その柔軟さが人工酸性液の 浸透を容易にしているために障害が発生しやすいのでは ないかとあ考えられるが，スギの測定 I の例ああり一概 にはいえない。

\section{$3-4$ 人工酸性液の組成之可視障害}

人工酸性液の散布実駼は主として葉によって行われる てとが多いが, いずれも硫酸, 硝酸, 塩酸等の人工酸性 液の組成について述べた研究報告は少ない。すっぱら酸 性度の比較, つまり水素イオン濃度の高低によって可視 障害の発生は左右されるとしている。しかし, 花弁によ る今回の測定結果では人工酸性液といってもその組成に よって障害の発現の仕方が相違するてとが明らかであっ た。花弁の色素の研究に打いては, フラボノイド類の色 素は存在する細胞液の $\mathrm{PH}$ にって, $\mathrm{PH}$ 值が減少する と変色するという報告ああるが, 乙れは変色であって脱 色ではない。人工酸性液による可視障害は水素イオンに よるものだけでなく, 硫酸, 硝酸, 塩酸といったそれぞ れの化学性に起因するあのあ考えるべきである。ての色 素と酸性液との研究をさらに進めることによって, 酸性 液の脱色作用に敏感な色素の発見が可能であり, 乙れは また, 植物の酸性雨に対する指標性の検討にも有効であ ると考えられる。

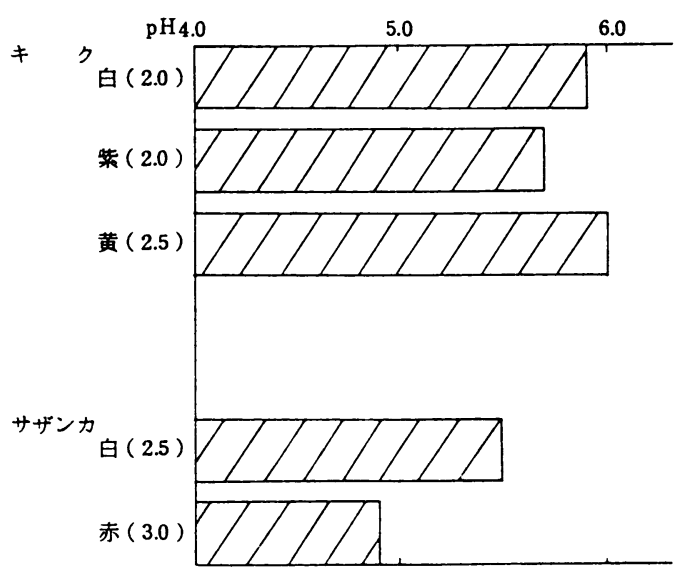

図一 1 花弁の $\mathrm{PH}$

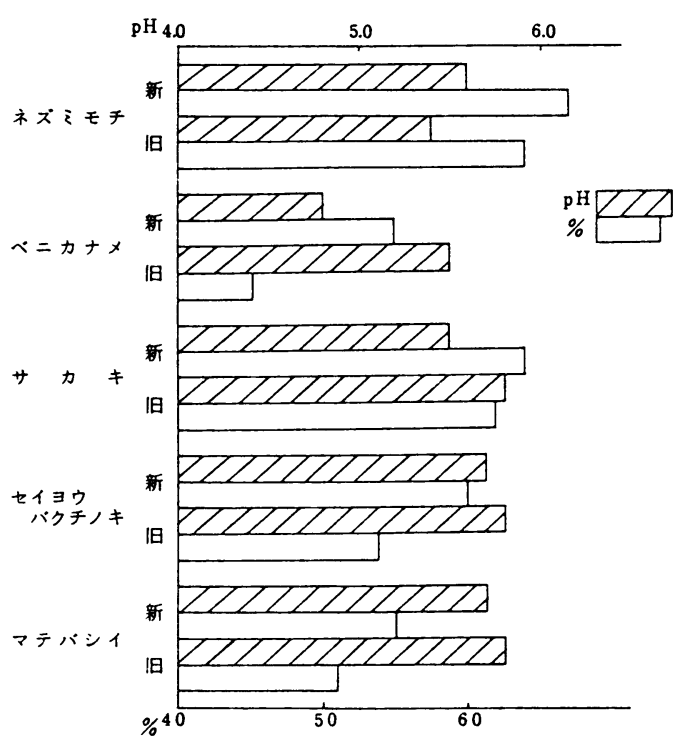

図一2 新葉と旧葉での $\mathrm{PH}$ と含水量

\section{4. まとめ及ひ今後の課題}

以上の実験の結果を総括すると,わが国の場合, 酸性 雨によって樹木の葉が可視障害を受けることはまず考え られない。しかし, 花弁では種類によっては障害が発現 する可能性はあり, 指標性を考える上では今後, より感 受性の高い種類や花色を検討することが必要であろう。

今回は植物の表面に酸性液を散布した上での障害の発 現をみてきたのであるが, 酸性物質は酸性雨だけでなく 固体, 気体状の大気污染物質の中にも存在する。乙の問 題を考えるためには, このようなものを含め酸性降下物 としてとらえる必要がある。また, 酸性雨による植物被 害の一方の問題は, 土壤の酸性化にともなう根系の活力 低下に関する点である。乙れらについてはいずれも今後 
の課題である。

なお, 本報は昭和60年度に千葉県環境部より受けた「環 境污染等が人体及び動植物に与える影響調查研究」の一 部をなすものであり, また, 国立公害研究所の啒託研究 員として行った研究の一環でもある。本研究の遂行にあ たっては, 千葉大学園芸学部緑地保全学講座の高橋啓二 教授之国立公害研究所大気環境計画室の植田洋匡室長の お世話をいただいた。こてに記して哚く感謝申し上げる 次第である。

\section{引用 文 献}

1) 大喜多敏一 ( 1977$)$ : 湿性大気污染一酸性降雨一: 公害之対策, Vol. 13 №. 7

2) 大喜多敏一 (1983)：酸性雨の物理と化学：公害と 対策, Vol. 19 No.12 Vol. 20 Na.12

3) 藤原喬・梅沢武・河野吉久 (1980)：酸性雨の数種 植物に対する試験ならびに文献調査 : 電力中央研究

\section{報告}

4）荒井邦夫・戸塚績（1979）：植物一土壌系への酸性 雨の影響：国立公害研究所報告 第10号

5 ）関東地方公害対策推進本部大気污染部会 (1981): 湿性大気污染調查報告書

6 ) 小山功・古明地哲人・小峰昌弘 (1985)：降水の低 $\mathrm{PH}$ 化とその気象条件：東京都公害研究所年報

7 ) 古明地哲人・小山功 (1985): 降水中化学成分濃度 の長期的推移亡その特性（II）：東京都公害研究所 年報

8 ）網川正男（1974）：酸性降雨による被害の発生と対 策：大気污染二ュース $\mathrm{Na.83}$

9) Likens, G. E. and Borman, F. H. (1977) : Acid rain Science 184

10）平石尹彦（1984）：酸性雨問題の把握：公害と対策 Vol. 20 Na 1

Summary : We investigated on damage to plants for landscaping by acid rain. We made some experiments on the damage to difference in hydrogen ion concentration of manmade acid rain, in the organs of plants and in the life stages of the leaves.

From the results, it is assumed that the leaves of trees and shurbs do not receive the damage visibly by acid rain in Japan. But, it is feared that the petals of some kinds of plants receive the damage by acid rain. So, investigations on plants susceptible to acid rain are necessary for the indication. 